\title{
NATIONAL PARKS IN BRITAIN
}

\begin{abstract}
$\mathrm{T}$ HE fourteenth report of the National Parks Com. mission covering the year ended September 30, 1963, emphasizes once more the need for amendment of the National Parks Act. This it does in a manner similar to that which it has urged the Government for many years: if the Park Planning Authorities are to possess the status and increased powers and financial resources which are required to meet the growing threats from development and from the use and misuse of the countryside by the public, amendments must be made to the Act. Even to conduct the comprehensive analytical surveys of each park necessary to determine the best way to provide for future needs calls for more technical staff than the Commission possesses, and inadequate resources appear to be frustrating the forward plans of the Commission itself and the Park Planning Authorities. While the Minister has authorized discussions on the shape of possible legislation little hope is held out of Parliamentary time in the early future. Apart from this, the Commission is coming to the opinion that the kind of objectives it visualizes for the parks are unlikely to be achieved effectively unless there is some form or measure of public ownership, trusteeship or dedication over at least parts of these areas. The report stresses the importance of vigorous new thought about the future of the parks.
\end{abstract}

Appended to the report are some extracts from the speech of the chairman, Lord Strang, to the Conference of Park Planning Authorities at Scarborough in May 1963, in which he outlined some suggestions for positive policy, and with the extracts from Sir Keith Joseph's speech to the same conference this appendix of itself is a valuable contribution to constructive discussion. References are made to coastal preservation and development, on which the Minister has now issued a circular asking authorities with coastal boundaries to make a special investigation of their coastal areas in consultation with the National Parks Commission and the Nature Conservancy. Brief comments are included on the Conference on Water Resources in the North West, on the Water Resources Act, and on the Local Authorities Land Act; 1963, which will facilitate treatment of derelict land under an amend. ment to Section 89 of the National Parks Act, 1949. Thus the report is in the main a record of steady pursuit of the Commission's objectives, within the limit set by available resources. There is a note of appreciation of work done by senior boys from some Home Office approved schools.

The views of the Commission on the effect of the proposed railway closures are set forth in a letter to the Minister of Transport which is appended to the report. This letter asks the Minister to consider carefully certain matters relating to social benefit which may arise from the closure of lines or stations. If the closure leads to visitors forgoing their visits, a blow will be struck at the main purpose of the parks. Use of either public or private road transport is likely to lead to increased road congestion and a demand for more public transport, road improvements and parking places, which often cannot be met with.

* National Parks and Access to the Countryside Act, 1949. Fourteenth lieport of the National Park Commission for the year ended September 30 1963. Pp. vii $+84+8$ plates. (London: H.M.S.O., 1963.) 72s. net. out adverse effect on the character of many of the parks. These consequences need to be set against any savings in money terms arising from the proposed closures, and in view of the declared purpose of the National Parks Act, the Commission submits that, within limits, it would be equitable that national funds should be available to keep open lines or stations serving national parks.

A comprehensive survey was conducted of the tourist industry in the Peak District National Park and the warden service was further augmented. In the Lake District Park the voluntary warden service was also expanded, and the Planning Board advanced its plans for a caravan site at Neaum Crag, Skelwith Bridge. In Snowdonia an agreement was reached on the Joint Advisory Committee's Forestry Map under the voluntary scheme of consultation on private afforestation, and Prof. J. S. Allen's two reports on chalet development were approved by the Joint Advisory Committee. Orders designating the Isle of Wight and East Devon as areas of outstanding natural beauty were confirmed by the Minister, and Orders designating the Forest of Bowland and Chichester Harbour were submitted for confirmation. Improvements were made by local authorities in nine of the fifteen areas already designated, and proposals for the South Downs long-distance route were approved by the Minister as well as the Commission's report on the Dorset Coast Path from Studland to Lyme Regis, which completes the proposals for a South West Peninsula Coast Path.

Development questions continue to figure largely in the report, and during the year nearly 450 such proposals affecting landscape beauty in national parks were referred to the Commission. As regards electricity, it is encourag. ing to note that at one of the enquiries the Minister of Power expressed concerm that it should have been urged on behalf of the Electricity Board that the duty to have regard to the effect of proposals on amenities was subordinate to the Board's duty to maintain an efficient, co-ordinated and economical system of supply. The cost of undergrounding supply lines continues to be a difficulty, particularly in the North Riding of Yorkshire, where the North Eastern Electricity Board is reluctant to follow the practice of the North Western Electricity Board and spread this cost over all consumers in its area. The question has now gone to the Minister of Power, who elsewhere has refused consent to overhead transmission in the Glaslyn Estuary. It is obvious from the report that the routing of overhead transmission lines to avoid prejudice to natural beauty is of increasing difficulty and satisfactory alternative routes are often impossible to find. Aerial masts constitute a similar problem, and in the present report the Commission deplores the Minister's decision to allow the General Post Office to proceed with the erection of a radio tower at Goose Green, Wottonunder-Edge, in view of the great damage to unspoilt landscape. On the other hand, the Commission is encouraged by the care and forethought with which the route for the Lancaster-Penrith Motorway has been chosen by the Ministry of Transport to avoid the Lake District National Park except for a slight encroachment on the eastern edge.

\section{VERTEBRATE PALAONTOLOGY IN ALBERTA}

A CONFERENCE and field-trip on "Vertebrate Palæontology" was held in Alberta during August 29-September 3. The primary purpose of the conference was to review work done in vertebrate palæontology in
Alberts and adjacent Provinces, and to examine the possibilities for a more active programme of research in this field at the University of Alberta. It is well known that many dinosaurs have been collected during the past 